\title{
PENGARUH BRAND LOVE, BRAND SATISFACTION, BRAND TRUST TERHADAP PURCHASE INTENTION PRODUK GUCCI
}

\author{
Yohanna dan Tommy Setiawan Ruslim \\ Program Studi Manajemen, Fakultas Ekonomi dan Bisnis, Universitas Tarumanagara, Jakarta \\ Email: Helloyohanaaa@gmail.com
}

\begin{abstract}
The purpose of this study was to determine whether brand love, brand satisfaction, and brand trust have a positive influence on purchase intention of Gucci products. The sampling technique in this study using purposive sampling. This questionnaire was distributed to 115 respondents who know the Gucci brand and have at least one product from the Gucci brand. The research method used in this research is validity test, reliability test, sign of weight test, multicollinearity test, determination coefficient test, predictive relevance test, effect size test, path coefficients test, goodness of fit test, and hypothesis testing. Data analysis was processed with the help of SmartPLS software (v.3.3.2). The results of this study indicate that brand love has positive and significant results on purchase intention, brand satisfaction has a positive and significant result on purchase intention, brand trust has a positive and significant result on purchase intention.
\end{abstract}

Keywords: Brand Love, Brand Satisfaction, Brand Trust, Purchase Intention.

\begin{abstract}
Abstrak: Tujuan penelitian ini adalah untuk mengetahui apakah brand love, brand satisfaction, dan brand trust memiliki pengaruh positif terhadap purchase intention pada produk Gucci. Teknik pengambilan sampel dalam penelitian ini menggunakan purposive sampling. Kuesioner ini disebarkan kepada 115 responden yang mengetahui brand Gucci dan setidaknya memiliki satu produk dari brand Gucci. Metode penelitian yang digunakan pada penelitian ini adalah uji validitas, uji reliabilitas, uji sign of weight, uji multikolinearitas, uji koefisien determinasi, uji predictive relevance, uji effect size, uji pathcoefficients, uji goodness of fit, dan pengujian hipotesis. Analisis data diolah dengan bantuan software SmartPLS (v.3.3.2). Hasil penelitian ini menunjukkan bahwa brand love memiliki hasil yang positif dan signifikan terhadap purchase intention, brand satisfaction memiliki hasil yang positif dan signifikan terhadap purchase intention, brand trust memiliki hasil yang positif dan signifikan terhadap purchase intention.
\end{abstract}

Kata Kunci: Brand Love, Brand Satisfaction, Brand Trust, Purchase Intention.

\section{LATAR BELAKANG}

Perkembangan dalam dunia fashion di Indonesia khususnya kalangan remaja hingga dewasa. Perkembangan ini menjadikan masyarakat sebagai masyarakat yang selektif di dalam menentukan gaya hidupnya. Gaya hidup sangat erat hubungannya dengan fashion, karena adanya fashion akan menunjang penampilan seseorang agar lebih menarik dan menjadi trend center di masyarakat. Dengan kata lain, fashion bisa dikatakan sebagai jati diri seseorang atau komunitas tertentu. Mereka mengekspresikan dirinya lewat busana yang dipakai 
Produk fashion sendiri merupakan termasuk produk yang bisa dikonsumsi atau dipakai dalam jangka panjang. Walaupun harganya berbanding jauh dari produk fashion pasaran yang mudah ditemukan di pusat perbelanjaan terdekat, biasanya produk fashion high end lebih sulit ditemukan, dan hanya diperjualbelikan di pusat perbelanjaan tertentu yang menyediakan berbagai macam brand dari produk fashion high end.

Dikutip dari situs https://us.fashionnetwork.com/ Tren konsumsi barang-barang bermerek dengan harga fantastis itu terungkap dalam laporan Asia Luxury Index 2016 yang dilansir Reebonz, situs belanja online terbesar di Asia khusus untuk segmen produk fashion yang memberikan kedudukan tersendiri dalam kehidupan sosial seseorang. Sangat disayangkan di tahun 2020 dunia dikagetkan dengan adanya pandemi Covid-19 yang mengakibatkan hampir semua toko tutup karena aturan lockdown dan karantina mandiri. Begitu pula impor barang yang membutuhkan regulasi yang rumit dan memakan waktu cukup lama. Hal itu membuat banyak industri fashion terkapar, terutama sektor produk high-end.

Tak hanya Gucci yang harus kerja keras mengembalikan angka penjualan, Channel dan Louis Vuitton pun terpaksa menerapkan penyesuaian harga. Dikutip dari https://www.cnbcindonesia.com dan https://wolipop.detik.com penjualan di China jadi penyebab utama menurunnya performa Gucci di awal tahun 2020 karena banyak toko dan butik yang ditutup imbas virus Corona. Boston Consulting menghitung penurunan penjualan di tahun ini mencapai $35 \%$ akibat penutupan gerai secara bersamaan di seluruh dunia akibat pembatasan sosial dan lockdown.

Walaupun adanya penurunan pembelian produk dari merek Gucci, namun tidak sedikit juga konsumen yang tetap memiliki minat beli terhadap barang mewah seperti Gucci. Purchase intention disebabkan juga dengan adanya faktor pendukung yaitu seperti brand love. Keinginan konsumen untuk membeli barang mewah didorong oleh adanya kecintaan pada merek tersebut, yang dimana merek tersebut memiliki pengaruh yang cukup besar terhadap konsumennya, selain itu alasan seseorang bisa memiliki suatu perasaan khusus terhadap sebuah merek adalah dari status sosial, dimana generasi millennial cenderung membangun harga diri dengan membeli barang mewah agar tidak merasa malu atau tertinggal dari orang lain. Masyarakat milenial juga sangat dipengaruhi oleh masalah sosial yang mungkin bila seseorang menggunakan barang mewah akan menunjukkan pengaruh sosial mereka. Selain faktor brand love, faktor lainnya yang mendorong adanya purchase intention adalah brand satisfaction. Keinginan pembelian konsumen terhadap suatu merek bisa didapatkan dari adanya ekspektasi dari konsumen saat membeli produk dari suatu merek tertentu.

Ada juga faktor brand trust yang mendorong adanya purchase intention, dimana konsumen yang bersedia untuk bergantung pada produk dari suatu merek tertentu berdasarkan kepercayaan dan harapan. Dimana merek barang mewah sangat menghargai kepercayaan yang diberikan oleh konsumennya, oleh karena itu mulai dari kualitas bahan yang dipilih, kerapian, keindahan, kebersihan, juga kualitas pelayanan akan terus ditingkatkan agar konsumen merasa puas dan nyaman yang akan meningkatkan kepercayaan dari konsumen.

Pentingnya purchase intention dalam brand Gucci adalah untuk mengetahui faktor-faktor apa saja yang dapat mempengaruhi minat pembelian konsumen guna meningkatkan penjualan dan meningkatkan kualitas yang dimiliki brand Gucci, selain itu adanya brand love, brand satisfaction, brand trust akan membantu mengetahui bagaimana konsumen bisa memiliki niat beli dan juga konsumen dapat menikmati produk dari merek yang dipasarkan.

Berdasarkan latar belakang yang telah dikemukakan di atas, maka penulis tertarik untuk meneliti lebih dalam tentang "Pengaruh Brand Love, Brand Satisfaction, Brand Trust Terhadap Purchase Intention Produk Gucci”. 


\section{KAJIAN TEORI}

\section{Gambaran Umum Teori}

Theory of Planned Behaviour, yang di kembangkan oleh Ajzen (2011). Teori perilaku terencana (TPB) berteori bahwa sebelum meramalkan tindakan seseorang yang merupakan perilaku, pengukuran atas niat berperilaku harus diukur terlebih dahulu. Intensi menurut TPB merupakan fungsi langsung dari sikap, norma subjektif dan kontrol terhadap perilaku Ajzen (2011). Penelitian ini dilakukan dengan tujuan untuk memahami dan memprediksi niat perilaku pembelian produk dari luxury goods merek Gucci.

Pembelian merek mewah oleh konsumen sering kali didorong oleh persepsi tentang identitas diri, suatu perasaan diri sendiri yang ideal, perbandingan sosial, dan motivasi "diri" lainnya, Perasaan afektif yang kuat tersebut berfungsi sebagai landasan fundamental untuk hubungan merek konsumen yang tahan lama dan dekat Huber et al., (2015) seperti cinta merek. Terinspirasi oleh teori Lovemarks Roberts (2005) dalam Cho dan Fiore (2015) brand love memiliki tiga dimensi yaitu :

1. Cognitive (Mystery)

Misteri terbentuk oleh pengalaman langsung dan tidak langsung antara konsumen dengan produk dari suatu merek, dimana konsumen merasakan manfaat yang mereka cari dalam produk dari suatu merek tersebut.

2. Sensory (Sensuality)

Sensualitas terbentuk dari sensasi visual yang dirasakan konsumen dalam pengalaman langsung dengan produk dari suatu merek tertentu, dimana konsumen menganalisa produk dari merek tertentu.

3. Emotional (Intimacy)

Intimasi sebagian besar terbentuk konsumen oleh perasaan subjektif seperti kegembiraan, kebahagiaan dan kepuasan. Perasaan ini dibentuk dari pengalaman langsung konsumen dengan produk dari suatu merek tertentu.

Selain adanya aspek brand love, aspek lain yang mendukung adanya purchase intention adalah brand satisfaction. Brand Satisfaction yang diperoleh oleh konsumen karena adanya kepuasan disaat konsumen menggunakan produk dari sebuah merek tertentu. Pengertian brand satisfaction menurut Kotler dan Keller (2008) dengan tepat menyebutkan bahwa produk dengan kualitas terbaik membuat konsumen lebih puas. Ada juga faktor brand trust yang mempengaruhi purchase intention, Chen dan Chang (2012) menyebutkan bahwa peningkatan kualitas yang dipersepsikan meningkatkan kepuasan merek konsumen seiring dengan kepercayaan merek. Berdasarkan adanya aspek brand love, brand satisfaction, dan brand trust mengakibatkan adanya purchase intention.

\section{Brand Love}

Carroll dan Ahuvia (2006:81) menyatakan bahwa brand love adalah "degree of passionate emotional attachment a satisfied consumer has for a particular trade mark". Menurut Albert dan Merunka (2013:33) mendefinisikan brand love sebagai "the brand love relationship is deep and enduring, such that the loved brand is considered irreplaceable". Sedangkan menurut Ahuvia (2005:32) brand love adalah "more than a feeling, brand love is considered a real emotion".

Maka dapat disimpulkan bahwa brand love adalah keterikatan emosional yang dimiliki oleh konsumen terhadap suatu merek yang mempengaruhi reaksi positif dan evaluasi merek, hubungan cinta merek yang dihasilkan oleh konsumen akan dianggap tidak dapat digantikan oleh merek manapun. 
Terinspirasi oleh teori Lovemarks Roberts (2005) dalam Cho dan Fiore (2015). Terdapat 3 dimensi brand love yaitu cognitive (mystery), sensory (sensuality) dan emotional (intimacy).

\section{Brand Satisfaction}

Iglesias et al., (2011:2) menyatakan bahwa brand satisfaction adalah "satisfaction refers to the emotional reactions, which emphasizes the emotional construct". Menurut Severt (2002:522) brand satisfaction didefinisikan "as the affective condition resulting from an overall evaluation of all aspects making up a relationship (i.e. products, prices, a firm's physical facilities, and so on) and an overall evaluation of several interactions among the parties".Sedangkan menurut $\mathrm{He}, \mathrm{Li}$, dan Harris (2012:14) brand satisfaction adalah "satisfaction appears when the performance of a brand meets the anticipations of the purchaser".

Maka dapat disimpulkan bahwa brand satisfaction adalah suatu perasaan positif yang dihasilkan oleh konsumen terhadap suatu merek tertentu, konsumen mengevaluasi seluruh aspek suatu produk dari merek tertentu seperti kualitas dan jenis produk, harga dari produk tersebut, kenyamanan tempat mereka membeli produk tersebut, juga kepuasan merek dihasilkan dari kinerja suatu produk dari merek tertentu memenuhi antisipasi konsumen.

\section{Brand Trust}

Chaudhuri dan Holbrook (2001:74) menyatakan bahwa brand trust adalah "brand trust is a factor that makes an average user believe that brand will perform its stated purpose whatsoever". Menurut Hiscock (2001:82) mendefinisikan brand trust adalah "marketers always strive to establish and maintain an intense bond between the consumer and the brand, and the essential precursor to ensure this bond is to build brand trust". Sedangkan menurut Mckinney dan Benson (2013:80) brand trust yang adalah " $a$ brand that enjoys a high level of trust among its customers will also have a sustainable relationship with the customers, leading to a high volume of transactions".

Maka dapat disimpulkan bahwa brand trust sebagai kepercayaan konsumen terhadap suatu produk dari merek tertentu dalam menjalankan fungsinya, konsumen yang memiliki rasa percaya pada sebuah produk pada merek tertentu akan mengarah ke volume transaksi yang berkelanjutan atau lebih tinggi.

\section{Purchase Intention}

Tariq et al., (2013:317) menyatakan purchase intention adalah "purchase intention is the implied promise to one's self to buy the product again whenever one makes the next trip to the market". Menurut Wu et al., (2015:145) mendefinisikan purchase intention sebagai "purchase intention acts as a conjunction between consumer's concentration on buying a product and the likelihood of buying". Sedangkan menurut Lee et al., (2017:145) purchase intention adalah "purchase intention determines the strength of consumer willingness to purchase".

Maka dapat disimpulkan purchase intention adalah sebagai kesediaan konsumen dalam keinginan untuk membeli suatu produk dari merek tertentu.

\section{Keterkaitan antara Brand Love dengan Purchase Intention}

Penelitian yang dilakukan oleh Clarinda Rodrigues dan Paula Rodrigues (2019) memiliki hasil dari penelitian ini adalah brand love secara positif berpengaruh terhadap purchase intention konsumen Penelitian ini membahas tentang brand love pada generasi millenial yang melibatkan 115 mahasiswa sarjana berusia 18-25 tahun. Muhammad Yasin dan Amjad Shamim (2013) meneliti hubungan brand love dengan purchase intention pada industri telepon genggam di kota Islamabad dan Rawalpindi di Republik Islam Pakistan. Dan hasil yang diperoleh adalah purchase intention memiliki pengaruh positif terhadap brand love. Penelitian yang dilakukan oleh Chetna Kudeshia, Pallab Sikdar dan Arun Mittal (2016) yang meneliti tentang pengaruh brand love terhadap purchase intention 
Penelitian ini membahas social media (facebook) sebagai media pemasaran untuk menyelidiki apakah terdapat hubungan yang signifikan terhadap merek yang disukai pada halaman penggemar di facebook. Hasil dari penelitian ini adalah brand love secara positif memiliki pengaruh terhadap purchase intention.

\section{Keterkaitan antara Brand Satisfaction dengan Purchase Intention}

Dam Tri Cuong (2020) meneliti hubungan antara brand satisfaction terhadap purchase intention pada industri laptop di Vietnam. Dimana penelitian ini menggunakan data survey investigasi pembeli data penelitian dari 255 yang membeli di toko laptop di Ho Chi Minh, Vietnam. Hasil dari penelitian ini adalah brand satisfaction memiliki pengaruh positif terhadap purchase intention, Penelitian yang dilakukan oleh Vita Briliana dan Nathasya Esterita Juli Silaen (2019) juga meneliti mengenai pengaruh brand satisfaction terhadap purchase intention pada industri kosmetik di Indonesia. Penelitian ini menggunakan 124 responden valid dari 175 kuesioner yang disebarkan kepada followers @wardahbeauty di Instagram melalui fitur direct message. Dan hasil yang diperoleh adalah brand satisfaction memiliki pengaruh positif terhadap purchase intention. Seyed Ali Alavia, Sajad Rezaeib, Naser Valaeic dan Wan Khairuzzaman Wan Ismail (2016) juga meneliti pengaruh brand satisfaction terhadap purchase intention. Penelitian ini membahas tentang memahami pengambilan keputusan konsumen (CDM). Hasil dari penelitian yang diperoleh adalah brand satisfaction memiliki pengaruh positif terhadap purchase intention.

\section{Keterkaitan antara Brand Trust dengan Purchase Intention}

Pada penelitian yang dilakukan oleh Muhammad Kashif Javed, Ma Degong dan Talat Qadeer (2018) menunjukan brand trust memiliki pengaruh positif terhadap purchase intention Dimana penelitian ini menyebarkan kuesioner dengan total sampel sebanyak 328 orang responden. Penelitian yang dilakukan oleh Plavini Punyatoya (2014) memiliki hasil penelitian yang dimana brand trust memiliki pengaruh positif terhadap purchase intention. Pengumpulan data dilakukan secara pribadi kepada 223 responden di India. Lim Sannya, Aisha Nur Arina, Ratu Tasha Maulidya dan Ressy Putri Pertiwi (2020) juga meneliti pengaruh brand trust terhadap purchase intention. Pengumpulan data dilakukan menggunakan online survey terhadap 203 orang responden. Hasil dari penelitian menunjukan brand trust memiliki pengaruh positif terhadap purchase intention.

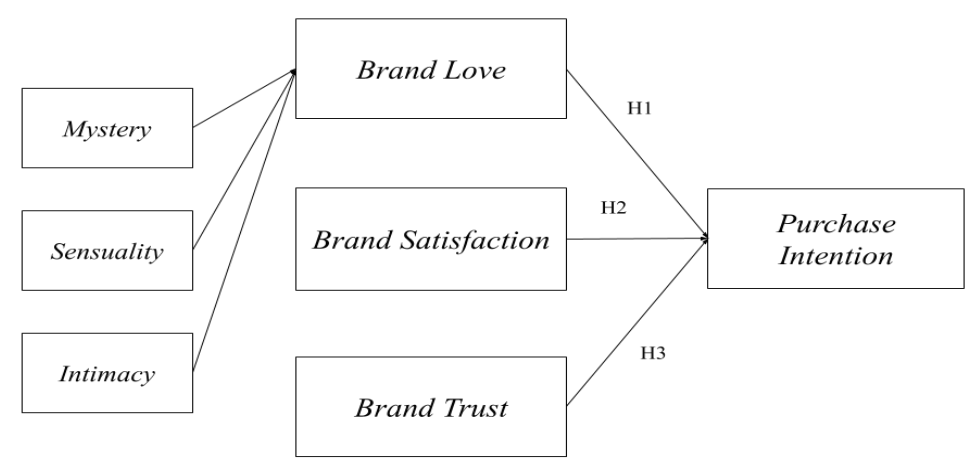

\section{Gambar 1. Model Penelitian}

Bersadarkan model penelitian, maka dapat dituliskan bahwa hipotesis yang diajukan 
dalam penelitian ini sebagai berikut:

$\mathrm{H}_{1}$ : Brand love memiliki pengaruh positif dan signifikan terhadap purchase intention brand Gucci di Jakarta.

$\mathrm{H}_{2}$ : Brand satisfaction memiliki pengaruh positif dan signifikan terhadap purchase intention brand Gucci di Jakarta.

$\mathrm{H}_{3}$ : Brand trust memiliki pengaruh positif dan signifikan terhadap purchase intention brand Gucci di Jakarta.

\section{METODOLOGI}

Desain penelitian yang digunakan yaitu desain penelitian deskriptif. Menurut Mccombs (2019) desain penelitian deskriptif sendiri memiliki kemampuan untuk menjelaskan tentang korelasi, kecenderungan, dan juga frekuensi variabel yang diteliti. Penelitian ini bertujuan untuk mengetahui pengaruh brand love, brand satisfaction, brand trust terhadap purchase intention brand Gucci di Jakarta. Penelitian ini menggunakan metode cross-sectional designs. Malhotra (2010) mengungkapkan bahwa cross-sectional designs yaitu jenis penelitian yang mengumpulkan informasi dari satu elemen populasi yang hanya dilakukan sekali saja.

Populasi dalam penelitian ini adalah seluruh pelanggan di daerah Jakarta yang mengetahui produk dari brand Gucci dan setidaknya memiliki satu produk dari brand Gucci. Teknik pemilihan sampel dalam penelitian ini adalah purposive sampling. Purposive sampling adalah teknik pengambilan sampel yang menentukan ciri-ciri khusus yang sesuai dengan tujuan penelitian. Sampel yang digunakan dalam penelitian ini adalah konsumen yang mengetahui produk dari brand Gucci dan setidaknya memiliki satu produk brand Gucci.

Menurut Sekaran (2000:227) persyaratan minimal dalam suatu penelitian yaitu sejumlah 30 responden untuk setiap kategori. Ukuran sampel yang efektif adalah lebih besar dari 30 dan kurang dari 500. Oleh karena itu, untuk mengoptimalkan hasil penelitian, maka jumlah sampel yang digunakan dalam penelitian ini adalah 115 responden.

Penelitian ini menggunakan Partial Least Square (PLS) dengan bantuan program SmartPLS (v.3.3.2). Structural Equation Modeling (SEM) dibagi menjadi dua, yaitu inner model dan outer model. Pada penelitian ini, analisis data yang akan dilakukan oleh outer model adalah uji validitas dan reliabilitas dan analisis data yang akan dilakukan pada inner model adalah uji koefisien determinasi $\left(\mathrm{R}^{2}\right)$, uji predictive relevance $\left(\mathrm{Q}^{2}\right)$, uji effect size $\left(\mathrm{f}^{2}\right)$, uji path coefficients, uji sign of weight, uji multikolinearitas, dan pengujian hipotesis.

\section{HASIL ANALISIS DATA}

\section{Uji Validitas}

Pada nilai Average Variance Extracted (AVE) memiliki nilai lebih dari 0,50. Hal ini menunjukkan bahwa setiap variabel yang digunakan telah memenuhi kriteria convergent validity. Pada nilai cross-loadings masing-masing variabel lebih besar dari pada nilai crossloadings variabel lainnya. Pada uji fornell-larcker dengan nilai akar kuadrat AVE dari masingmasing variabel lebih dari variabel lainnya. Hal ini menunjukkan bahwa setiap variabel yang digunakan dalam penelitian ini telah memenuhi kriteria discriminant validity.

\section{Uji Reliabilitas}

Pada hasil uji composite reliability dan cronbach's alpha memiliki nilai lebih dari 0,70 , maka masing-masing variabel yang digunakan dalam penelitian ini dapat dikatakan reliabel. 


\section{Pengujian Konstruk Penelitian}

Pada uji koefisien determinasi memiliki nilai $\mathrm{R}^{2}$ pada variabel brand love sebesar 0,453 yang artinya 45,3\% variasi variabel eksogen yaitu brand love dapat dijelaskan dengan dimensi cognitive (mystery), sensory (sensuality), dan emotional (intimacy). Nilai $\mathrm{R}^{2}$ pada variabel purchase intention sebesar 0,510 yang artinya 51,0\% variasi variabel endogen yaitu purchase intention dapat dijelaskan dengan variabel eksogen yaitu brand love, brand satisfaction dan brand trust. Sisanya sebesar 3,7\% dapat dijelaskan dengan variabel lainnya. Variabel purchase intention merupakan variabel moderat karena memiliki nilai $\mathrm{R}^{2}$ Sebesar 51,0\%.

Hasil uji predictive relevance memiliki nilai $\mathrm{Q}^{2}$ lebih dari 0 yaitu sebesar 0,233 untuk variabel brand love dan 0,322 untuk variabel purchase intention. Hal ini membuktikan bahwa konstruk variabel yang digunakan dalam penelitian ini relevan.

Uji effect size, variabel brand love terhadap purchase intention memiliki efek lemah yaitu dengan nilai 0,114. Variabel brand satisfaction memiliki efek lemah terhadap purchase intention dengan nilai yaitu 0,045. Variabel brand trust memiliki efek sedang terhadap purchase intention dengan nilai yaitu 0,136. Hasil uji effect size pada dimensi cognitive (mystery) memiliki efek lemah terhadap brand love dengan nilai yaitu 0,114. Dimensi sensory (sensuality) memiliki efek lemah terhadap brand love dengan nilai yaitu 0,044. Dimensi emotional (intimacy) memiliki efek lemah terhadap brand love dengan nilai yaitu 0,087 .

Tabel 1

Hasil Bootstrapping

\begin{tabular}{|l|c|c|c|}
\hline \multicolumn{1}{|c|}{ Variabel } & $\begin{array}{c}\text { Path } \\
\text { Coefficients }\end{array}$ & t-statitics & p-values \\
\hline Brand Love $\rightarrow$ Purchase Intention & 0,293 & 3,807 & 0,000 \\
\hline Brand Satisfaction $\rightarrow$ Purchase Intention & 0,219 & 2,238 & 0,026 \\
\hline Brand Trust $\rightarrow$ Purchase Intention & 0,341 & 4,137 & 0,000 \\
\hline
\end{tabular}

Tabel 2 (dimensi brand love)

Hasil Bootstrapping

\begin{tabular}{|l|c|c|c|}
\hline \multicolumn{1}{|c|}{ Variabel } & $\begin{array}{c}\text { Path } \\
\text { Coefficients }\end{array}$ & t-statitics & p-values \\
\hline Cognitive (mystery) $\rightarrow$ Brand Love & 0,284 & 3,302 & 0,001 \\
\hline Sensory (sensuality) $\rightarrow$ Brand Love & 0,223 & 1,981 & 0,048 \\
\hline Emotional (intimacy) $\rightarrow$ Brand Love & 0,309 & 2,342 & 0,020 \\
\hline
\end{tabular}

Berdasarkan Tabel 1, dapat dilihat bahwa variabel brand love memiliki pengaruh terhadap purchase intention secara signifikan dengan nilai path coefficients sebesar 0,239. Variabel brand satisfaction memiliki pengaruh terhadap purchase intention secara signifikan dengan nilai path coefficients sebesar 0,219. Variabel brand trust memiliki pengaruh terhadap purchase intention secara signifikan dengan nilai path coefficients sebesar 0,341. Pada Tabel 2, dapat dilihat bahwa dimensi cognitive (mystery) memiliki pengaruh yang signifikan terhadap brand love dengan nilai path coefficients sebesar 0,284. 
Dimensi sensory (sensuality) memiliki pengaruh yang signifikan terhadap brand love dengan nilai path coefficients sebesar 0,223. Dimensi emotional (intimacy) memiliki pengaruh yang signifikan terhadap brand love dengan nilai path coefficients sebesar 0,309.

Hasil perhitungan Goodness of Fit dapat disimpulkan bahwa nilai GoF memiliki kecocokan yang bernilai besar dengan nilai GoF sebesar 0,60

\section{Tabel 3}

\section{Hasil Pengujian Hipotesis}

\begin{tabular}{|c|l|c|}
\hline Hipotesis & \multicolumn{1}{|c|}{ Pernyataan } & Hasil \\
\hline $\mathrm{H}_{1}$ & $\begin{array}{l}\text { Brand love memiliki pengaruh positif dan signifikan } \\
\text { terhadap purchase intention brand Gucci di Jakarta. }\end{array}$ & Tidak Ditolak \\
\hline $\mathrm{H}_{2}$ & $\begin{array}{l}\text { Brand satisfaction memiliki pengaruh positif dan } \\
\text { signifikan terhadap purchase intention brand Gucci } \\
\text { di Jakarta. }\end{array}$ & Tidak Ditolak \\
\hline $\mathrm{H}_{3}$ & $\begin{array}{l}\text { Brand trust memiliki pengaruh positif dan } \\
\text { signifikan terhadap purchase intention brand Gucci } \\
\text { di Jakarta }\end{array}$ & Tidak Ditolak \\
\hline
\end{tabular}

\section{DISKUSI}

Pada pengujian hipotesis pertama dapat dilihat bahwa variabel brand love memiliki pengaruh positif dan signifikan terhadap variabel purchase intention pada brand Gucci di Jakarta. Pada penelitian ini dapat dilihat bahwa dimensi cognitive (mystery) memiliki pengaruh paling besar pada variabel brand love, dimana konsumen memiliki minat yang lebih terhadap brand Gucci dalam memilih sebuah kualitas dan model pada produk. Hasil daripada penelitian ini sesuai dengan hasil penelitian yang dilakukan oleh Clarinda Rodrigues dan Paula Rodrigues (2019) dengan judul "Brand love matters to Millennials: the relevance of mystery, sensuality and intimacy to neo-luxury brands". Pada penelitian tersebut menunjukkan bahwa brand love berpengaruh positif terhadap purchase intention.

Pada pengujian hipotesis kedua menunjukan bahwa variabel brand satisfaction memiliki pengaruh positif dan signifikan terhadap variabel purchase intention pada brand Gucci di Jakarta. Hasil penelitian ini sesuai dengan hasil penelitian yang dilakukan oleh Vita Briliana dan Nathasya Esterita Juli Silaen (2019) dengan judul penelitian "Creating Purchase Intention Throughs Positive Electronic Wom, Brand Attitude, Satisfaction, and Brand Awareness. Case of Wardah Exclusive Lip Cream on Instagram”. Di dalam penelitian tersebut menegaskan bahwa kepuasan terhadap suatu produk atau jasa akan diperiksa setelah mereka mengkonsumsi produk tersebut. Hal utama yang mempengaruhi kepuasan konsumen adalah ekspektasi mereka sebelum mengkonsumsi suatu produk atau membeli suatu jasa.

Pada pengujian hipotesis ketiga menunjukan bahwa variabel brand trust memiliki pengaruh positif dan signifikan terhadap variabel purchase intention pada brand Gucci di Jakarta. Hasil penelitian ini sesuai dengan penelitian yang dilakukan oleh Lim Sanny, Aisha Nur Arina, Ratu Tasha Maulidya dan Ressy Putri Pertiwi (2020) dengan judul penelitian "Purchase intention on Indonesia male's skin care by social media marketing effect towards brand image and brand trust". Di dalam penelitian tersebut menjelaskan bahwa adanya pengaruh kepercayaan merek dan niat beli yang artinya jika kepercayaan merek meningkat maka nilai niat beli akan meningkat. 


\section{PENUTUP}

Bagi peneliti selanjutnya diharapkan untuk menambahkan jumlah responden agar hasil penelitian lebih representatif. Peneliti juga dapat menggunakan variabel lain yang mempengaruhi purchase intention selain dari variabel yang digunakan dalam penelitian ini, seperti Brand Image, Brand Loyalty, eWOM.

\section{DAFTAR PUSTAKA}

Ahuvia, A.C. (2005). Beyond the extended self: loved objects and consumers' identity narratives. Journal of Consumer Research, 32(1),171-184. (https://doi.org/10.1086/429607)

Ajzen, I. (2011). The theory of planned behaviour: Reactions and reflections.

Albert, N. \& Merunka, D. (2013). The role of brand love in consumer-brand relationships.

Journal of Consumer Marketing, 30(3), 258-266. (https://doi.org/10.1108/07363761311328928)

Alavi, S. A., Rezaei, S., Valaei, N., \& Wan Ismail, W. K. (2016). Examining shopping mall consumer decision-making styles, satisfaction and purchase intention. The

International Review of Retail, Distribution and Consumer Research, 26(3), 272-303. (https://doi.org/10.1080/09593969.2015.1096808)

Briliana, V., \& Silaen, N. E. J. (2019). Creating Purchase Intention Throughs Positive

Electronic Wom, Brand Attitude, Satisfaction, and Brand Awareness. Case of Wardah Exclusive Lip Cream on Instagram. (http://dx.doi.org/10.4108/eai.6-12-2018.2286282)

Carroll, B.A. \& Ahuvia, A.C. (2006). Some antecedents and outcomes of Brand love,

Marketing Letters, 17(2),79-89. (https://doi.org/10.1007/s11002-006-4219-2)

Chaudhuri, A. \& Holbrook, M.B. (2001). The chain of effects from brand trust and brand affect to brand performance: the role of brand loyalty, Journal of Marketing, 65(2), 81-93. (https://doi.org/10.1509/jmkg.65.2.81.18255)

Chen, Y.-S., \& Chang, C.-H. (2012). Enhance green purchase intentions: The role of green perceived value, green perceived risk, and green trust. Journal of Business Ethics, 50(3), 502-520. (https://doi.org/10.1108/00251741211216250)

Cho, E. \& Fiore, A.M. (2015). Conceptualization of a holistic brand image measure for fashionrelated brands, Journal of Consumer Marketing, 32(4), 255-265. (https://doi.org/10.1108/JCM-07-2014-1063)

Cuong, D. T. (2020). The role of brand trust as a mediator in the relationship between brand satisfaction and purchase intention. International Journal of Psychosocial

Rehabilitation, 24(6), 14726-14735. (DOI: 10.37200/IJPR/V24I6/PR261416)

Hiscock, J. (2001). Most trusted brands, Marketing, 1(3), 32-33.

He, Hongwei, Li, Yan, \& Harris, Lloyd. (2012). Social identity perspective on brand loyalty. Journal of Business Research, 65(5), 648-657. (https://doi.org/10.1016/j.jbusres.2011.03.007)

Huber, F., Meyer, F. \& Schmid, D.A. (2015). Brand love in progress-the interdependence of brand love antecedents in consideration of relationship duration, Journal of Product \& Brand Management, 24(6), 567-579. (https://doi.org/10.1108/JPBM-08-2014-0682)

Kotler, P. \& Keller, K.L. (2008). Manajemen Pemasaran. Edisi Ketiga Belas. Jilid I Jakarta: Erlangga. 
Kudeshia, C., Sikdar, P., \& Mittal, A. (2016). Spreading love through fan page liking: A perspective on small scale entrepreneurs. Computers in Human Behavior, 54, 257-270. (https://doi.org/10.1016/j.chb.2015.08.003)

Lee, W.I., Cheng, S.Y. \& Shih, Y.T. (2017). Effects among product attributes, involvement, wordof-mouth, and purchase intention in online shopping. Asia Pacific Management Review, 22(4), 1-7. (https://doi.org/10.1016/j.apmrv.2017.07.007)

Malhotra, Naresh K. (2010). Riset Pemasaran Marketing Research (Edisi 4 Jilid 1). New Jersey, Indonesia: PT. Indeks.

Muhammad Kashif Javed ,Ma Degong , \& Talat Qadeer , (2017 ) " Importance of Financial Knowledge and Self-Esteem in Determining Individuals' Financial Behavior ",

International Journal of Management and Applied Science (IJMAS), 3(10), 46-50.

McCombes, S. (2019). Descriptive research. Retrieved from https://www.scribbr.com/methodology/descriptive-research/

Mckinney, M.E. \& Benson, A. (2013). The value of brand trust. Journal of Brand Strategy, 2 (1), 76-86.

Punyatoya, P. (2014). Linking environmental awareness and perceived brand eco-friendliness to brand trust and purchase intention. Global Business Review, 15(2), 279-289. (https://doi.org/10.1177/0972150914523572)

Roberts, K. (2005). Lovemarks: The Future Beyond Brands, (2nd ed). Powerhouse Books.

New York : NY. Dalam Cho, E., Fiore, A.M. \& Russell, D.W. (2015). Validation of a fashion Brand image scale capturing cognitive, sensory, and affective associations: testing its role in an extended Brand equity model, Psychology \& Marketing, 32(1), 28-48.

Rodrigues, C., \& Rodrigues, P. (2019). Brand love matters to Millennials: the relevance of mystery, sensuality and intimacy to neo-luxury brands. Journal of Product \& Brand Management. (https://doi.org/10.1108/JPBM-04-2018-1842)

Sanny, L., Arina, A., Maulidya, R., \& Pertiwi, R. (2020). Purchase intention on Indonesia male's skin care by social media marketing effect towards brand image and brand trust. Management Science Letters, 10(10), 2139-2146. (DOI : 10.5267/j.msl.2020.3.023)

Sekaran, Uma. (2000). Research Methods For Business: A Skill-Building Approach, (3rd ed), John Wiley \& Sons: Inc.

Severt, E. (2002). The customer's path to loyalty: a partial test of the relationships of prior experience, justice, and customer satisfaction. Virginia Polytechnic Institute and State University, Blacksburg : VA.

Iglesias, O., Singh, J.J., \& Batista-Foguet, J.M. (2011). The role of innovated brand experience and affective commitment in determining brand loyalty. Journal of Brand

Management, 18(8), 570-582. (https://doi.org/10.1057/bm.2010.58)

Tariq, M.I., Nawaz, M.R., Nawaz, M.M. \& Butt, H.A. (2013). Customer perceptions about branding and purchase intention: a study of FMCG in an emerging market. Journal of Basic and Applied Scientific Research, 3(2), 340-347.

Wu, J.H., Wu, C.W., Lee, C.T. \& Lee, H.J. (2015). Green purchase intentions: an exploratory study of the Taiwanese electric motorcycle market. Journal of Business Research, 68(4), 829-833. (https://doi.org/10.1016/j.jbusres.2014.11.036) 
Yohanna dan Ruslim: Pengaruh Brand Love, Brand Satisfaction, Brand Trust...

Yasin, M., \& Shamim, A. (2013). Brand love: Mediating role in purchase intentions and word-ofmouth. Journal of Business and Management, 7(2), 101-109. 